\title{
Spatiotemporal Variation of Siberian Crane Habitats and the Response to Water Level in Poyang Lake Wetland, China
}

\author{
Lin Zou ${ }^{1}$, Bisong $\mathrm{Hu}^{1,2, * \mathbb{C}}$, Shuhua $\mathrm{Qi}^{3}$, Qianqian Zhang ${ }^{1}$ and Pan Ning ${ }^{1}$ \\ 1 School of Geography and Environment, Jiangxi Normal University, Nanchang 330022, China; \\ 201940100063@jxnu.edu.cn (L.Z.); zhangqianqian@jxnu.edu.cn (Q.Z.); ningpan@jxnu.edu.cn (P.N.) \\ 2 State Key Laboratory of Resources and Environmental Information System, Institute of Geographic Sciences \\ and Natural Resources Research, Chinese Academy of Sciences, Beijing 100101, China \\ 3 Key Laboratory of Poyang Lake Wetland and Watershed Research, Ministry of Education, Jiangxi Normal \\ University, Nanchang 330022, China; qishuhua11@jxnu.edu.cn \\ * Correspondence: hubisong@jxnu.edu.cn
}

Citation: Zou, L.; Hu, B.; Qi, S.; Zhang, Q.; Ning, P. Spatiotemporal Variation of Siberian Crane Habitats and the Response to Water Level in Poyang Lake Wetland, China. Remote Sens. 2021, 13, 140. https://doi.org/ $10.3390 /$ rs13010140

Received: 12 December 2020 Accepted: 30 December 2020 Published: 4 January 2021

Publisher's Note: MDPI stays neutral with regard to jurisdictional clai$\mathrm{ms}$ in published maps and institutional affiliations.

Copyright: () 2021 by the authors. Licensee MDPI, Basel, Switzerland. This article is an open access article distributed under the terms and conditions of the Creative Commons Attribution (CC BY) license (https:// creativecommons.org/licenses/by/ $4.0 /)$.
Abstract: The Poyang Lake wetland in China is the largest wintering destination for Siberian cranes worldwide. Understanding the spatiotemporal characteristics of crane habitats is of great importance for ecological environment governance and biodiversity protection. The shallow water, grassland, and soft mudflat regions of the Poyang Lake wetland are ideal habitats for wintering Siberian cranes. Based on Landsat Thematic Mapper (TM), Enhanced Thematic Mapper Plus (ETM+), and Operational Land Imager (OLI) remote sensing images, habitat areas were extracted and associated with various water levels taken on multiple dates. Landscape metrics were applied to describe the spatial structural characteristics of the crane habitats, and spatial statistics are used to explore the cold and hot spots of their distribution. Moreover, three indicators including sustainability, stability, and variety were applied to evaluate the vulnerability of the crane habitats under different hydrological conditions. Our findings indicate: (a) The main crane habitats exhibit a gradual decreasing degree of fragmentation in time, an obvious uncertainty of shape complexity and a relatively stable connectivity. (b) The crane habitats have a consistent spatial pattern of highly aggregated distributions associated with various water levels. (c) The hot spots of the habitats formed multiple "sheet" belts centered on the "Lake Enclosed in Autumn" regions, while the cold spots indicate a spatial pattern of axial distributions. (d) The majority of the hot spots of the habitats were distributed in sub-lakes found in the southeast part of the Poyang Lake watershed and the Nanjishan and Wucheng nature reserves, while the cold spots were mainly distributed in the main channels of the basins of Poyang Lake. (e) The sustainable habitats were mainly distributed in the "Lake Enclosed in Autumn" regions and intensively aggregated in two national nature reserves. (f) Under conditions of extremely low to average water levels (5.3-11.46 m), an increase of water level causes a decrease of the stability and variety of the crane habitats and weakens the aggregation structure.

Keywords: Siberian crane; habitat; Geographic Information System; vulnerability; Poyang Lake; Landsat images

\section{Introduction}

The Siberian crane (Leucogeranus leucogeranus), a large wading bird, has been identified as one of the critically endangered species on the International Union for Conservation of Nature (IUCN) 2018 Red List, with a total number of about 3500 worldwide [1]. Approximately $98 \%$ of wintering Eastern Siberian cranes migrate from their breeding grounds in the Arctic tundra of northeastern Russia to the Poyang Lake wetland in China [2]. The unique Poyang Lake wetland ecosystem provides important habitats for millions of wintering waterbird species throughout the world and provides a remarkable service function to these populations via its diverse and abundant habitats $[3,4]$. 
The water level of Poyang Lake has been abnormally low in recent years, especially in autumn and winter, which significantly affects the main food sources and habitats of Siberian cranes [5-7]. In addition, the hydrological processes of the Poyang Lake wetland have also undergone changes because of human activities, such as flood control, hydropower, irrigation, aquaculture, and water conservancy projects [8-10]. In particular, the "Lake Enclosed in Autumn" project, a long-term fishing operation mode adapted to the seasonal hydrological changes of Poyang Lake, has also been identified to have a negative impact on the local ecological environment [11,12]. It is formed by constructing low dams during the dry seasons and enclosing shallow beaches on the spot, which are located around the sub-lakes of Poyang Lake, to intercept more fish and water when the water recedes in autumn $[13,14]$. This involves the use of seasonal shallow saucer lakes for aquaculture of fish farming and includes the majority of the shallow saucer lakes in the Poyang Lake wetland area [15]. The hydrological situation of Poyang Lake is the main influence factor that determines the quality of Siberian crane habitats [16,17]. Therefore, it is of great importance for ecological environment protection and management of the Poyang Lake wetland to study the spatiotemporal variation of Siberian crane habitats and their corresponding response to water level changes.

Many previous studies have explored the ecological habits and habitat selection of migratory birds, such as suitable habitats [18-20], foraging behaviors [21-24], and overnight accommodation [25]. In terms of the environmental health assessment of migratory bird habitats, previous approaches have investigated spatiotemporal variations of habitats [26-29], amount characteristics and migration patterns [30,31], vegetation structure [32-34], biodiversity [35-37], etc. Studies of the influencing factors of migratory bird habitats mainly focus on the exploring of the relationships between environmental factors [38-40], hydrological factors [41,42], and migratory bird habitats. The changes of water level and hydrological processes are a dominant factor that can significantly induce the variations of migratory bird habitats in area and structure. Meanwhile, a variety of quantitative techniques have evaluated migratory bird habitats, such as the vulnerability index [43], habitat efficiency index [44], Geographic Information System (GIS) and remote sensing (RS) technologies [45,46], and fuzzy comprehensive evaluation [47]. More recent studies have focused on the impact assessment of human activities on migratory bird habitats, such as fisheries [48-50], dredging [51], and water conservation projects [52-54].

This study aims to identify suitable habitats of the wintering Siberian crane in the Poyang Lake wetland, and explores the characteristics of spatial distribution and temporal changes of crane habitats under various water levels by applying a landscape classification process. To do this we explore the correlation, heterogeneity, and dependence of the crane habitats at multiple spatial and temporal scales. In addition, we test the vulnerability of Siberian crane habitats associated with various water levels. The proposed approaches can be extended to extract the suitable habitats of wintering migratory birds in other wetlands and evaluate the corresponding spatiotemporal variation and the response to water level. Our findings provide support for decision-making on the protection of migratory Siberian cranes in the Poyang Lake wetland, which might be focused on the maintenance of key protected areas and the discovery of potential habitats, as well as the countermeasures to protect the habitat under different water levels.

\section{Materials and Methods}

\subsection{Study Area}

Poyang Lake $\left(28^{\circ} 22^{\prime}-29^{\circ} 45^{\prime} \mathrm{N}, 115^{\circ} 47^{\prime}-116^{\circ} 45^{\prime} \mathrm{E}\right)$ is a seasonal throughput lake and the largest freshwater lake in China, located on the southern bank of the middle and lower reaches of the Yangtze River in northern Jiangxi Province, China (Figure 1). The boundary of the Poyang Lake natural wetland was identified based on high-water level determined from pixels extracted from a Landsat ETM+ image taken on 30 July 2003, excluding river courses, breakwaters, and aquaculture waters [55]. This natural wetland is a special wetland ecosystem, with the characteristics of a system of large lakes during high water 
levels and of riverine channels and swamps during low water levels [56]. Because of its rich plant, fish and other species diversity, this lake is important for the protection of global biodiversity and is an important winter migration destination for various migratory birds. Nearly $98 \%$ of the world Siberian cranes population, $50 \%$ of the white-naped crane (Grus vipio) population, and $60 \%$ of the wild geese population spend their winters in the Poyang Lake wetland [57]. Several national nature reserves have been established in the Poyang Lake wetland to protect the overwintering migratory birds. The wetland separates into many sub-lakes of various size during drought and periods of low water, however during periods of high water reconnect a one water body. The main lake water bodies are located in the eastern and western banks of Poyang Lake (Figure 1). They are seasonal natural saucer lakes, most of which are mainly located in the two nature reserves, and the "Lake Enclosed in Autumn" regions are mainly scattered in these sub-lakes [13].

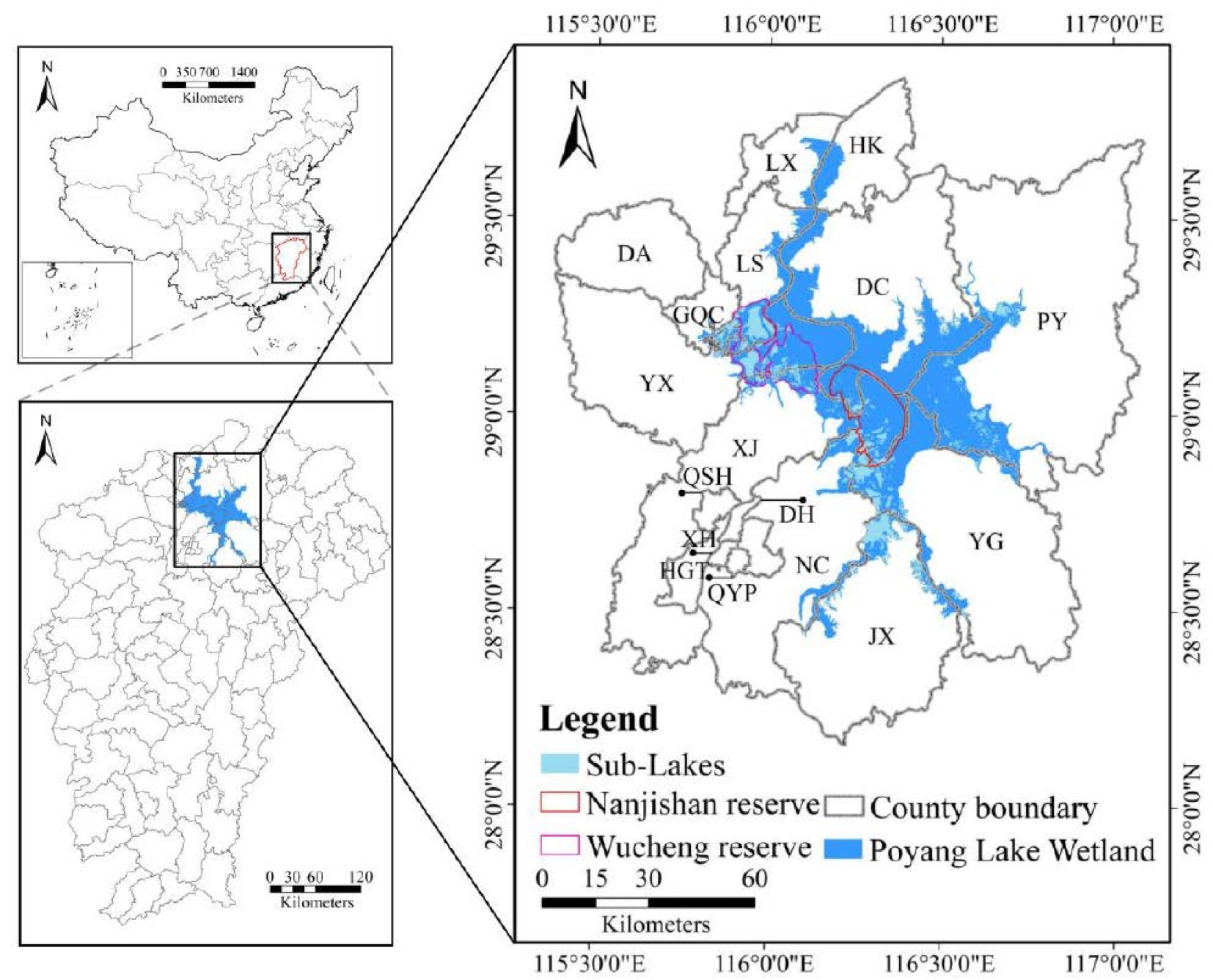

Figure 1. Locations of the Poyang Lake wetland, the sub-lakes and the national nature reserves (names of the county around Poyang Lake are abbreviated as follows: DA, Dean; DC, Duchang; DH, Donghu; GQC, Gongqingcheng; HGT, Honggutan; HK, Hukou; JX, Jinxian; LS, Lushan; LX, Lianxi; NC, Nanchang; PY, Poyang; QSH, Qinshanhu; QYP, Qinyunpu; XH, Xihu; XJ, Xinjian; YG, Yugan; and YX, Yongxiu).

\subsection{Data and Pre-Processing}

The fundamental geographical datasets used in this study include the administrative division data of the study area, the Poyang Lake natural wetland boundary, and the boundaries of two national nature reserves (Wucheng and Nanjishan). The area of habitats and foraging grounds of the wintering migratory birds is significantly reduced under high 
water levels, and it is difficult to maintain demand for migratory birds [16,58]. As this is an obvious adverse factor affecting the crane habitats, we are more concerned about the spatiotemporal variation of the crane habitats under other water levels that are conducive to the habitat maintenance. Therefore, three hydrological conditions were considered as important to the variations of the Siberian crane habitats, including extremely low water level, low water level, and average water level. We selected 15 scenes of TM/ETM+/OLI remote sensing images from 1993 to 2016 acquired by Landsat satellite under clear weather in autumn and winter (from October to March of the following year), which is consistent to the wintering period of the Siberian cranes in Poyang Lake wetland; detailed information is shown in Table 1. The remote sensing image data were collected from the geospatial data cloud platform (http:/ / www.gscloud.cn). The water level data are from observations of the Xingzi Hydrological Station of Poyang Lake, which is a nationally controlled hydrological station. Its water level monitoring has a long history and strong continuity, and the water level changes here adequately represent the overall trend of the water level change of Poyang Lake.

Table 1. Landsat TM/ETM+/OLI images used in this study and the corresponding water levels at the Xingzi gauging station.

\begin{tabular}{cccc}
\hline Hydrological Conditions & $\begin{array}{c}\text { Image Acquired Date } \\
\text { (YYYY/MM/DD) }\end{array}$ & Sensor & $\begin{array}{c}\text { Water Level at Xingzi Station } \\
\text { (Yellow Sea Elevation) }\end{array}$ \\
\hline Extremely low water level & $1993 / 1 / 31$ & TM & $6.69 \mathrm{~m}$ \\
& $2004 / 2 / 15$ & TM & $5.30 \mathrm{~m}$ \\
$5.88 \mathrm{~m}$ & $5.96 \mathrm{~m}$ & $5.80 \mathrm{~m}$ \\
& $2007 / 1 / 6$ & ETM+ & $5.81 \mathrm{~m}$ \\
Low water level & $2010 / 1 / 14$ & OLI & $7.45 \mathrm{~m}$ \\
& $2014 / 1 / 9$ & OLI & $7.90 \mathrm{~m}$ \\
& $2015 / 2 / 13$ & TM & $8.13 \mathrm{~m}$ \\
Average water level & $1995 / 12 / 7$ & TM & $8.28 \mathrm{~m}$ \\
& $2000 / 1 / 27$ & ETM+ & $7.40 \mathrm{~m}$ \\
& $2004 / 11 / 29$ & OLI & $11.10 \mathrm{~m}$ \\
& $2008 / 12 / 10$ & TM & $10.82 \mathrm{~m}$ \\
\end{tabular}

The types of Siberian crane habitats in the Poyang Lake wetland are soft mudflat, shallow water, and grassland [16,26,59-61], which are the main suitable areas for Siberian cranes to avoid natural enemies. These three types of areas have different habitat functions for Siberian cranes. Wet grassland is the main area for Siberian cranes to avoid natural enemies, and shallow water is the occasional alternative. According to the optimal foraging theory, soft mudflat and shallow water areas are the main feeding places for Siberian cranes and the best habitat options, which are far away from human disturbance. Accordingly, we implemented remote sensing classification of various types of Siberian crane habitats under various water levels in the Poyang Lake wetland. The technical process is shown in the left part of Figure 2. All Landsat images were geometrically corrected to the World Geodetic System-1984 Coordinate System (WGS-84) using the Universal Transverse Mercator (UTM) coordinate system, and orthorectified based on a digital elevation model (DEM) with a 30-meter spatial resolution, which was interpolated from 1:50,000 topographic maps from Jiangxi Provincial Bureau of Surveying and Mapping. The iterative self-organizing data analysis technique algorithm (ISODATA) was applied to implement the unsupervised classification to generate 10-pixel clusters with corresponding spectral similarity. The spectral clusters were first recorded and labeled as four landscape types, including water, sand, bare soil, and grassland, and then visually interpreted. Unsupervised classification of water surface and bare soil pixels was carried out again. According to visual interpretation 
and water depth estimation, water surface was classified into deep and shallow water areas. Based on visual interpretation and the normalized difference water index (NDWI) threshold, bare soil was divided into hard soil and soft mudflat areas. In total, six landscape types, including deep water, shallow water, sand, grassland, hard soil, and soft mudflat, were extracted using a consistent 30-meter resolution. Finally, the suitable habitat areas of Siberian cranes in the Poyang Lake wetland were collected and associated with various water levels taken on multiple dates (Figure 3). A total of 120 reference locations were created for the accuracy assessment of the classification. The assessment result indicated an overall accuracy of over $91 \%$ and a kappa coefficient of over 0.89 for the 15 land-cover maps. Detailed information is shown in Table 2.

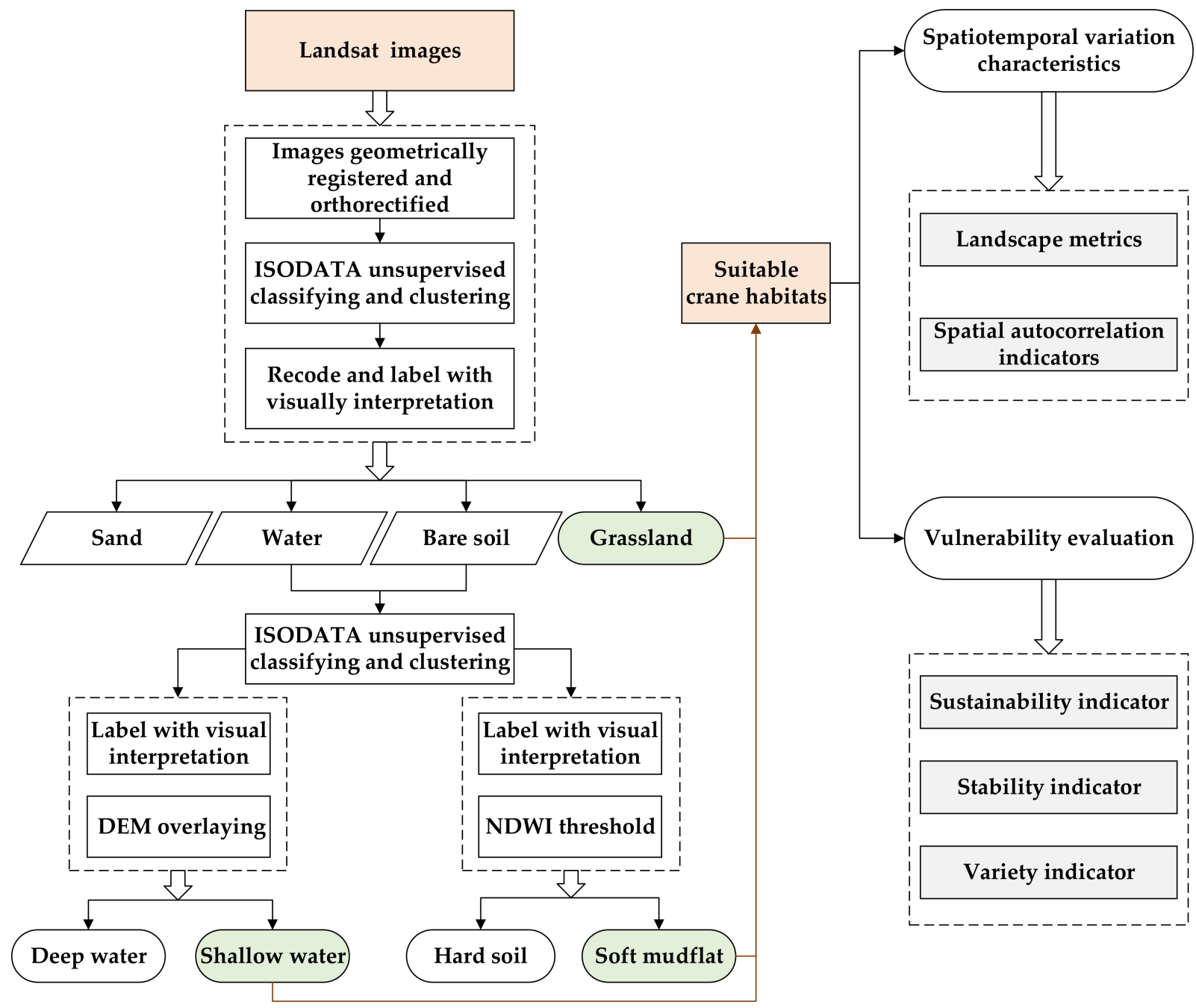

Figure 2. Research design flowchart of the Poyang Lake wetland landscape classification (left part) and the analyses of the spatiotemporal variation of Siberian crane habitats (right part). 


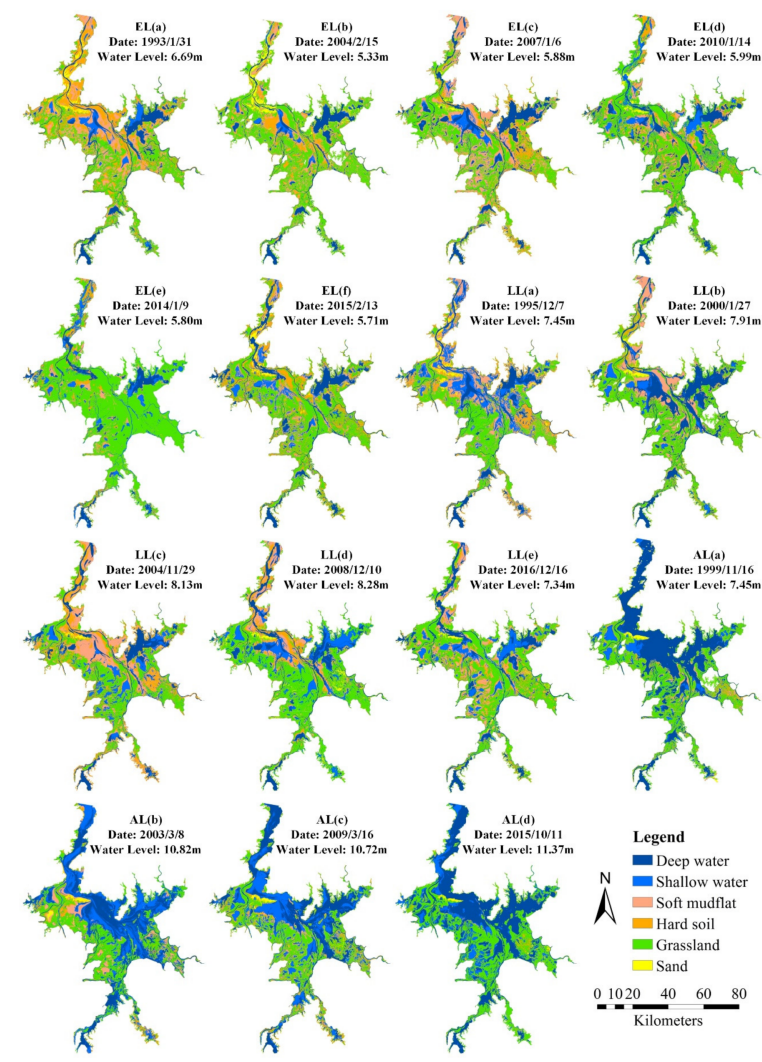

Figure 3. Poyang Lake wetland landscapes with various water levels (EL: extremely low level; LL: low level; AL: average level).

Table 2. Accuracy assessment details of the wetland landscape classification.

\begin{tabular}{cccc}
\hline $\begin{array}{c}\text { Date } \\
(\text { YYYY/MM/DD) }\end{array}$ & Sensor & Overall Accuracy (\%) & Kappa Coefficient \\
\hline $1993 / 1 / 31$ & TM & 94.17 & 0.9313 \\
$2004 / 2 / 15$ & TM & 92.50 & 0.9117 \\
$2007 / 1 / 6$ & ETM+ & 95.00 & 0.9411 \\
$2010 / 1 / 14$ & ETM+ & 96.67 & 0.9545 \\
$2014 / 1 / 9$ & OLI & 94.17 & 0.9326 \\
$2015 / 2 / 13$ & OLI & 91.67 & 0.9083 \\
\hline $1995 / 12 / 7$ & TM & 93.33 & 0.9215 \\
$2000 / 1 / 27$ & TM & 95.00 & 0.9217 \\
$2004 / 11 / 29$ & ETM+ & 90.83 & 0.8918 \\
$2008 / 12 / 10$ & ETM+ & 90.83 & 0.8920 \\
$2016 / 12 / 16$ & OLI & 92.50 & 0.9132 \\
\hline $1999 / 11 / 16$ & TM & 96.67 & 0.9607 \\
$2003 / 3 / 8$ & TM & 92.50 & 0.9081 \\
$2009 / 3 / 16$ & ETM+ & 91.67 & 0.9034 \\
$2015 / 10 / 11$ & OLI & 94.17 & 0.9309 \\
\hline
\end{tabular}

\subsection{Methods}

After the suitable crane habitats associated with various water levels taken on multiple dates were extracted, the subsequent analyses include exploring the spatiotemporal variation characteristics and evaluating the vulnerability (see the right part of Figure 2). The former was accomplished using landscape pattern indices and spatial autocorrelation indicators. The landscape metrics help describe the spatial structure characteristics of the crane habitats, and the spatial statistics can be used to indicate the hot and cold spots 
of their distribution. The vulnerability of the Siberian crane habitats in the Poyang Lake wetland were evaluated using three indicators: sustainability, stability, and variety.

\subsubsection{Landscape Metrics}

The landscape pattern indices can help quantitatively describe the spatial landscape pattern information, indicate the structural composition, reflect the spatial configuration, and find potentially meaningful regularity in the landscape [62-65]. We selected several landscape metrics that can reflect the spatial variation characteristics of Siberian crane habitats, including LPI, AREA_MEAN, SHAPE_AM, PAFRAC, and AI (see Table 3 for a detailed description). The calculation of these metrics was implemented in the Fragstats software, and the results were used to analyze temporal changes in the area, shape, and layout of the wintering Siberian crane habitat landscape in the Poyang Lake wetland.

Table 3. Description of the landscape metrics applied to explore the crane habitat pattern.

\begin{tabular}{cll}
\hline Full Name & Abbreviation & \multicolumn{1}{c}{ Description } \\
\hline Largest patch index & LPI & $\begin{array}{l}\text { The proportion of the area of the largest patch to the overall landscape area, } \\
\text { which characterizes the degree of landscape fragmentation. }\end{array}$ \\
\hline $\begin{array}{c}\text { Mean patch area } \\
\text { index }\end{array}$ & AREA_MN & $\begin{array}{l}\text { The average of patch area for each landscape type. It is also used to } \\
\text { characterize the degree of landscape fragmentation. }\end{array}$ \\
$\begin{array}{c}\text { Area-weighted mean } \\
\text { shape index }\end{array}$ & SHAPE_AM & $\begin{array}{l}\text { The average of patch shape index weighted by the relative patch size, which } \\
\text { helps describe the complexity of the patch shapes and examines the changes in } \\
\text { landscape shape. }\end{array}$ \\
$\begin{array}{c}\text { Perimeter area } \\
\text { fractal dimension } \\
\text { index }\end{array}$ & PAFRAC & $\begin{array}{l}\text { The average of patch shape complexity. PAFRAC ranges from 1 to } 2 \text { and the } \\
\text { larger PAFRAC value indicates the more complex landscape pattern. }\end{array}$ \\
\hline Aggregation index & AI & $\begin{array}{l}\text { The ratio of the number of similar adjacencies to the maximum one for each } \\
\text { landscape type, when the type is clustered into a plaque to the greatest extent. } \\
\text { AI is usually multiplied by 100 to express as a percentage. It is applied to } \\
\text { explore the non-randomness or aggregation degree of different patch types in } \\
\text { the landscape. }\end{array}$ \\
\hline
\end{tabular}

\subsubsection{Spatial Autocorrelation Indicators}

The spatial distribution of Siberian crane habitats can directly reflect the function and development of the Poyang Lake wetland. In order to understand the distribution pattern of the habitats at different periods, and considering the great difference in the area of natural wetland division of Poyang Lake, the natural wetland area was firstly gridded into 4189 grids of $1 \mathrm{~km} \times 1 \mathrm{~km}$ [66-68]. The global Moran's I indicator was then applied to measure the global autocorrelation of Siberian crane habitats in the Poyang Lake wetland. Finally, the local autocorrelation of the Siberian crane habitats was measured by the Getis-Ord $G^{*}$ indicator to further identify the distribution of cold and hot spots.

Moran's I is one of the earliest and most widely used spatial autocorrelation indicators [69], given by:

$$
I=\frac{n \sum_{i=1}^{n} \sum_{j=1}^{n} w_{i j}\left(x_{i}-\bar{x}\right)\left(x_{j}-\bar{x}\right)}{\sum_{i=1}^{n} \sum_{j=1}^{n} w_{i j} \sum_{i=1}^{n}\left(x_{i}-\bar{x}\right)^{2}}
$$

where $I$ is the measurement of the studied global spatial autocorrelation, $x_{i}$ denotes the observation value at location $i, \bar{x}$ represents the average value of all the locations in the study area, $w_{i j}$ denotes the spatial adjacency between locations $i$ and $j$, and $n$ is the number of areas. The value of Moran's $I$ indicator ranges from -1 to 1 and the larger absolute value of Moran's I statistic indicates the stronger global spatial autocorrelation. 
The Getis-Ord $G^{*}$ indicator can effectively reflect the local spatial correlation of the observations around a specific location [70], which is defined as:

$$
G_{i}^{*}=\frac{\sum_{j=1}^{n} w_{i j} x_{j}-\bar{x} \sum_{j=1}^{n} w_{i j}}{\sqrt{\sum_{j=1}^{n} x_{j}^{2} / n-\bar{x}^{2}} \sqrt{\left(n \sum_{j=1}^{n} w_{i j}^{2}-\left(\sum_{j=1}^{n} w_{i j}\right)^{2}\right) /(n-1)}}
$$

where $G_{i}^{*}$ is the measurement of the studied local spatial autocorrelation at location $i$, and $x_{j}$ denotes the observation value at location $j$ which is adjacent to location $i$. The statistically significant $z$-score value of the $G^{*}$ indicator indicates the local spatial clustering. The larger positive $z$-score values identify stronger high-value clustering (hot spots) and the larger negative ones identify stronger low-value clustering (cold spots).

\subsubsection{Vulnerability Evaluation Indicators}

The vulnerability of Siberian crane habitats in the Poyang Lake wetland was evaluated from three aspects, including the sustainability, the stability and the variety. For a specific location, the consistency of the habitat under different water level conditions indicates the corresponding sustainability. The sustainability indicator is defined for a specific location to reflect the maintenance of the habitat at different water levels. A location is considered to have the strongest sustainability when it is suitable for the crane habitats under all the water levels. According to multiple datasets of the habitat distributions under different water level conditions, the sustainable crane habitats in the studied area can be calculated by the spatial intersection:

$$
S=S_{E L} \cap S_{L} \cap S_{A L}
$$

where $S$ is the raster dataset of the sustainable crane habitats in the studied area, and $S_{E L}$, $S_{L}$ and $S_{A L}$ denote the datasets of the habitats at the extremely low, low, and average water levels, respectively. The symbol " $\cap$ " indicates the spatial intersection analysis of multiple raster datasets. The calculation can be easily implemented in ArcGIS platform (ESRI). In the sustainability results, the cells with the value of 1 indicate the locations of the sustainable crane habitats under a specific water level or all the water levels. Those locations which are unsuitable for the crane habitats under any water levels are assigned with null cell values.

For a certain water level, multiple Landsat images were collected to derive the landscapes and the corresponding habitats. The stability indicator is defined to indicate the relative suitability of a specific location in multiple habitat datasets at the same water level. A location is considered to have the strongest stability under a specific water level when it is suitable for the crane habitats according to all the landscape datasets under that water level. The stabilities of all the locations for each water level can be calculated by the cell statistics of the multiple raster datasets:

$$
S_{i}^{(\delta)}=\sum_{j=1}^{n(\delta)} v_{i, j}^{(\delta)}
$$

where $\delta$ is the symbol representing water levels, including extremely low level (EL), low level (LL), and average level (AL). $S_{i}^{(\delta)}$ denotes the calculation of the stability at location $i$ under water level $\delta . n(\delta)$ is the number of the landscape datasets under water level $\delta . v_{i, j}^{(\delta)}$ denotes the cell value of location $i$ in the $j$ th landscape dataset under water level $\delta$. It equals to 1 if the location is suitable for the crane habitats. The calculation of the stability indicator is implemented cell by cell throughout the whole study area under three water levels. The cells with the stability value of zero are assigned with null values. The stability indicator ranges from 1 to 6 (EL), from 1 to 5 (LL), or from 1 to 4 (AL) and higher value indicates stronger stability of the crane habitats under a specific water level.

Finally, we considered the local cohesive structure of the suitable crane habitats under different water level conditions. For each water level, a variety indicator is defined to 
identify the distinct number of the stabilities in a local neighborhood for each raster cell. If the stabilities vary a lot within a local neighborhood of a location under a specific water level, the other cells surrounding it are hard to maintain the consistent stability, and it introduces a high variety of the crane habitats within a local neighborhood. The corresponding calculation of the variety indicator can be implemented by the focal statistics of the raster dataset:

$$
V_{i}^{(\delta)}=\oplus\left\{S_{j}^{(\delta)}, j \in N_{i}^{*}\right\}
$$

where $V_{i}^{(\delta)}$ is the calculation of the variety at location $i$ under water level $\delta . N_{i}^{*}$ denotes a specific local neighborhood of location $i$ and a default $12 \times 12$ (cells) rectangular neighborhood was applied in this study. $S_{j}^{(\delta)}$ is the stability value under water level $\delta$ at location $j$ which is contained within the neighborhood of location $i$. The symbol " $\oplus$ " indicates an operator to count the distinct number of an integer set, which includes all the stability values with a specific neighborhood of a specific location. Note that the null stability value is also counted as a unique number during the variety calculation. Therefore, the variety indicator ranges from 1 to 7 (EL), from 1 to 6 (LL) or from 1 to 5 (AL) and higher value indicates stronger variety of the crane habitats under a specific water level.

\section{Results}

\subsection{Composite Variations of Siberian Crane Habitats}

The landscapes of the Poyang Lake wetland associated with various water conditions help describe the spatiotemporal patterns of the Siberian crane habitats. Table 4 gives the statistics of the landscape types at different water levels taken on various dates and Table 5 lists the area statistics of the crane habitats within the Poyang Lake wetland boundary and within the two national nature reserves. Grassland contributed the largest proportion to the Poyang Lake wetland landscapes at various water levels (Table 4). The areas of the crane habitats in the Poyang Lake wetland exhibited a temporal increasing then decreasing tendency at extremely low and average water levels, whereas the temporal tendency was opposite at low water levels (Table 4). The areas of the crane habitats in the two nature reserves indicated similar temporal characteristics as the whole wetland under similar hydrological conditions (Table 5). The landscapes and the crane habitats in the Poyang Lake wetland exhibited obvious responses to different water levels at different times.

Table 4. Areas of landscape types in the Poyang Lake wetland under various water level conditions $\left(\mathrm{km}^{2}\right)$.

\begin{tabular}{|c|c|c|c|c|c|c|c|}
\hline $\begin{array}{l}\text { Hydrological } \\
\text { Conditions }\end{array}$ & $\begin{array}{c}\text { Date } \\
\text { (YYYY/MM/DD) }\end{array}$ & Deep Water & $\begin{array}{l}\text { Shallow } \\
\text { Water }\end{array}$ & Soft Mudflat & $\begin{array}{c}\text { Hard } \\
\text { Soil }\end{array}$ & Grassland & Sand \\
\hline \multirow{6}{*}{$\begin{array}{c}\text { Extremely low } \\
\text { water level }\end{array}$} & $1993 / 1 / 31$ & 415.11 & 292.74 & 735.31 & 878.65 & 1044.04 & 84.87 \\
\hline & $2004 / 2 / 15$ & 414.72 & 182.09 & 599.90 & 408.78 & 1510.62 & 147.34 \\
\hline & $2007 / 1 / 6$ & 620.14 & 202.64 & 1000.95 & 444.13 & 1153.36 & 29.46 \\
\hline & $2010 / 1 / 14$ & 557.11 & 394.49 & 508.28 & 399.63 & 1550.08 & 41.14 \\
\hline & $2014 / 1 / 9$ & 259.88 & 435.33 & 262.78 & 232.16 & 2246.67 & 13.89 \\
\hline & $2015 / 2 / 13$ & 502.48 & 416.28 & 439.65 & 710.35 & 1301.78 & 80.19 \\
\hline \multirow{5}{*}{ Low water level } & $1995 / 12 / 7$ & 466.10 & 696.60 & 730.19 & 459.79 & 993.47 & 104.56 \\
\hline & $2000 / 1 / 27$ & 887.17 & 230.52 & 658.38 & 232.62 & 1247.46 & 49.93 \\
\hline & $2004 / 11 / 29$ & 491.65 & 433.93 & 762.68 & 731.98 & 995.44 & 35.04 \\
\hline & $2008 / 12 / 10$ & 484.87 & 587.58 & 467.45 & 298.72 & 1531.41 & 80.68 \\
\hline & $2016 / 12 / 16$ & 485.12 & 503.42 & 554.89 & 399.34 & 1433.30 & 56.24 \\
\hline \multirow{4}{*}{$\begin{array}{c}\text { Average water } \\
\text { level }\end{array}$} & $1999 / 11 / 16$ & 1341.56 & 397.93 & 257.37 & 152.63 & 1100.29 & 56.30 \\
\hline & $2003 / 3 / 8$ & 910.44 & 1005.32 & 284.70 & 262.17 & 953.55 & 34.56 \\
\hline & $2009 / 3 / 16$ & 867.58 & 912.09 & 336.75 & 261.24 & 1021.87 & 51.19 \\
\hline & 2015/10/11 & 1315.19 & 622.30 & 100.25 & 102.08 & 1270.00 & 40.89 \\
\hline
\end{tabular}


Table 5. Areas of crane habitats in the Poyang Lake wetland and two national nature reserves under various water level conditions $\left(\mathrm{km}^{2}\right)$.

\begin{tabular}{ccccc}
\hline $\begin{array}{c}\text { Hydrological } \\
\text { Conditions }\end{array}$ & $\begin{array}{c}\text { Time } \\
\text { (YYYYMM/DD) }\end{array}$ & Poyang Lake Natural Wetland & Nanjishan Nature Reserve & Wucheng Nature Reserve \\
\hline & $1993 / 1 / 31$ & 2072.09 & 259.15 & 239.85 \\
Extremely & $2004 / 2 / 15$ & 2292.61 & 282.70 & 277.36 \\
Low & $2007 / 1 / 6$ & 2356.95 & 295.75 & 288.07 \\
Water & $2010 / 1 / 14$ & 2452.85 & 244.76 & 282.92 \\
Level & $2014 / 1 / 9$ & 2944.78 & 328.03 & 274.75 \\
& $2015 / 2 / 13$ & 2157.71 & 272.03 & 286.74 \\
& $1995 / 12 / 7$ & 2420.27 & 299.20 & 292.92 \\
Low & $2000 / 1 / 27$ & 2136.36 & 225.05 & 243.57 \\
Water & $2004 / 11 / 29$ & 2192.06 & 282.70 & 296.69 \\
Level & $2008 / 12 / 10$ & 2586.44 & 309.83 & 297.07 \\
& $2016 / 12 / 16$ & 2491.61 & 264.46 & 297.86 \\
Average & $1999 / 11 / 16$ & 1755.59 & 182.81 & 277.73 \\
Water & $2003 / 3 / 8$ & 2243.56 & 259.51 & 292.23 \\
Level & $2009 / 3 / 16$ & 2270.70 & 293.31 & 261.98 \\
\hline
\end{tabular}

\subsection{Landscape Characteristics of Siberian Crane Habitats}

The calculation of the landscape metrics reflects the temporal characteristics of the landscape structure composition and the spatial allocation of the habitats (Figure 4), in addition to the area changes of the crane habitats. The LPI and AREA_MN indexes can represent the fragmentation degree of the landscape, and results showed characteristics of fluctuating growth (Figure 4a,b). The fragmentation degree of the main crane habitats in the Poyang Lake wetland gradually decreases in time. However, the temporal fluctuations of LPI and AREA_MN indexes revealed the instability of landscape composition during the development process. Two indexes describing the complexity of patch shape, SHAPE_AM and PAFRAC, clearly fluctuated with time (Figure 4c,d). Their temporal curves showed characteristics of irregularity and disorder, and the shape complexity of the main winter crane habitats exhibited no obvious temporal patterns. The temporal change of the AI index of the crane habitats showed a slightly constant tendency (Figure 4e), which fluctuated less than $6 \%$ relative to the average, indicating a relatively stable connectivity of the crane habitats. However, the AI indexes of the shallow water and soft mud regions fluctuated in time, which is associated to the unique hydrological characteristics of Poyang Lake. The receding of water and the corresponding appearance of mudflats are frequent in dry seasons due to the decrease of water level. The change of water level leads to frequent alternations between water surface and land, and the habitats of wintering migratory birds significantly change in shallow water and soft mudflat landscapes $[10,54]$.

\subsection{Spatial Autocorrelations of Siberian Crane Habitats}

We further explored the spatial autocorrelation and the corresponding temporal changes of the suitable habitat distribution. Under three distinct hydrological conditions (extremely low, low and average water levels), the global Moran's I indicators of gridded distributions of the crane habitats were calculated and located in the range of $0.6-0.7$ $(p<0.05)$. The crane habitat distributions associated with all water level conditions indicated extremely strong positive spatial autocorrelations and a consistent spatial pattern of highly aggregated distributions. 


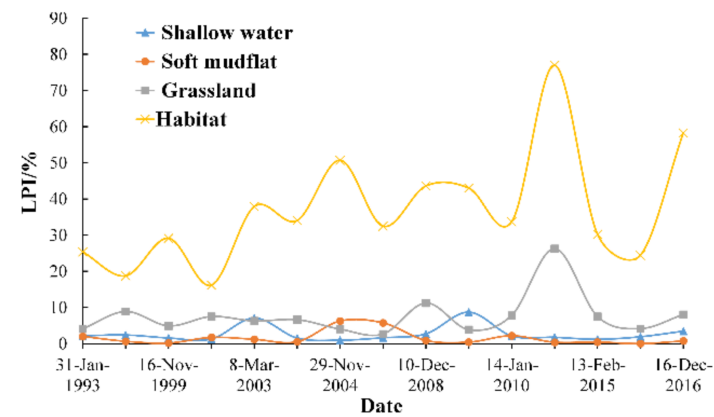

(a)

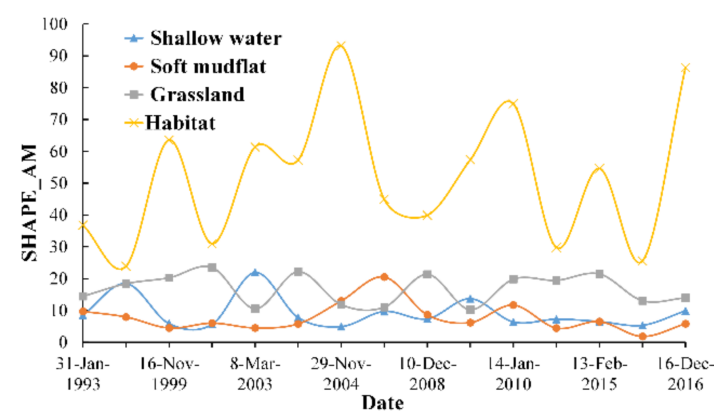

(c)

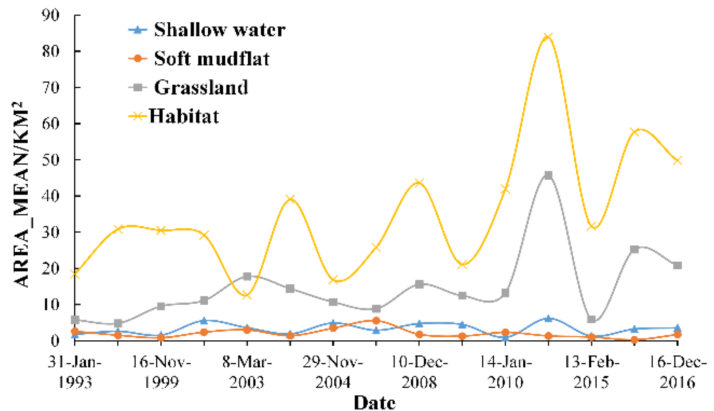

(b)

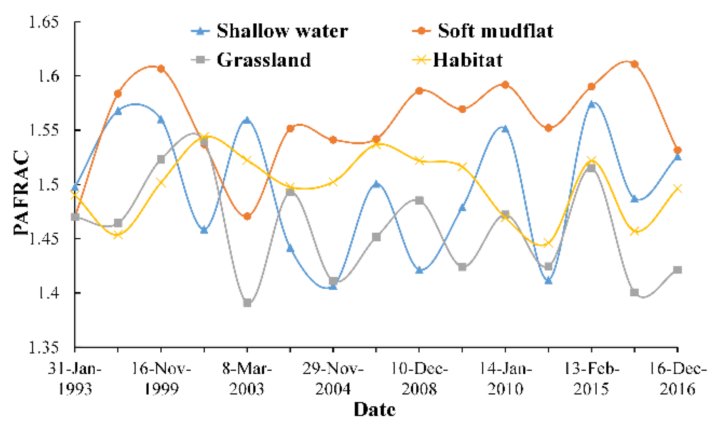

(d)

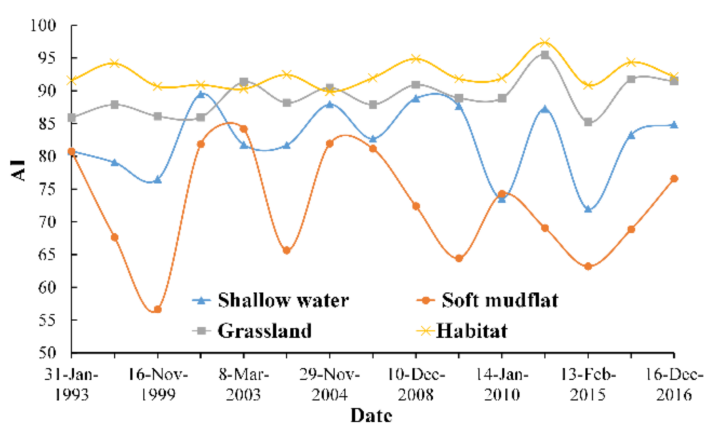

(e)

Figure 4. Temporal changes of landscape metrics of the crane habitats in the Poyang Lake wetland: (a) LPI; (b) AREA_MEAN; (c) SHAPE_AM; (d) PAFRAC; (e) AI.

The $G^{*}$ indicator was then applied to detect the local autocorrelations of the crane habitat distributions. The spatial heterogeneities of gridded crane distributions were explored for different water levels and dates, and the corresponding hot and cold spots of the suitable habitat distribution for Siberian cranes were identified (Figure 5). The hot spots of the crane habitats exhibited a consistent "sheet" structure under different hydrological conditions and were gradually evolving over time to form multiple "sheet" belts centered on the "Lake Enclosed in Autumn" regions. The majority of hot spots were distributed in sub-lakes in the southeast part of Poyang Lake, and in the vicinity of the Nanjishan and Wucheng nature reserves. Conversely, the cold spots indicated a spatial pattern of axial distributions and were mainly distributed along the main channels of the Poyang Lake basin from the inlets to the outlets. In addition, several sub-lakes located in the southern, eastern and middle parts of Poyang Lake were also the cold spots of crane habitat distributions. 


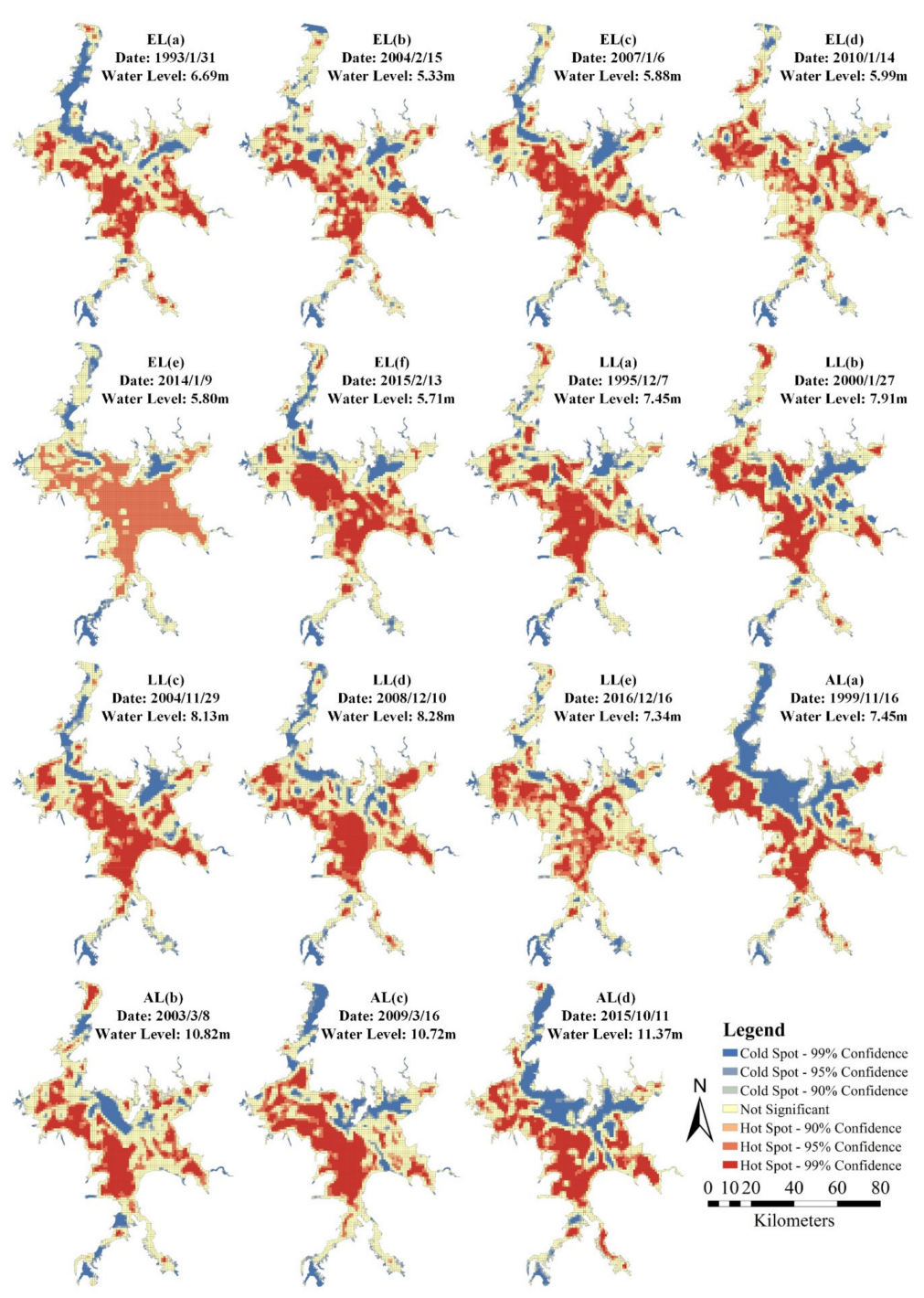

Figure 5. Hot and cold spots of the crane habitats in the Poyang Lake wetland found under different water levels at various dates (EL: extremely low level; LL: low level; AL: average level).

\subsection{Vulnerability Evaluations of Siberian Cranes Habitats}

The vulnerability of the Siberian crane habitats in the Poyang Lake wetland were evaluated by three indicators: sustainability, stability and variety. The non-null values of the sustainability results indicate the locations of the sustainable crane habitats under a specific water level. In the stability and variety results, higher cell values indicate stronger stability and variety of the crane habitats. These results have different value ranges under different water levels, and to intuitively demonstrate them, we applied the standard-deviation stretch method to convert the numeric values into color gradients in the corresponding thematic maps.

The sustainability metric was generally consistent with the hot spot distribution found from the local spatial autocorrelation results. The most sustainable habitats were distributed in the "Lake Enclosed in Autumn" regions located on the west and east sides of Poyang Lake (Figure 6a). Additionally, the most sustainable crane habitats were primarily aggregated in the Nanjishan and Wucheng nature reserves on the west bank of Poyang Lake (Figure $6 \mathrm{~b}, \mathrm{c}$ ). The stability metric exhibited an extremely weak distribution in the main channels and in several sub-lakes located in the southern, eastern and middle parts of the Poyang Lake (Figure 7), which was partly consistent with the cold spots of the crane habitat distributions. However, an extremely weak distribution of variety was mainly found in the non-habitat areas of the Siberian cranes (Figure 8). 
The stability and variety of suitable habitats for wintering Siberian cranes in the Poyang Lake wetland had a clear relation to all hydrological conditions considered. The stability of the crane habitats decreased with an increase of water level (Figure 7), especially in the main lake area below the main channel of Poyang Lake. Details of the area statistics of stabilities are shown in Table 6 . The null cells with the stability value of zero contributed $2.08 \%, 4.81 \%$, and $9.32 \%$ of the wetland area under extremely low, low, and average water levels, respectively. The proportions of the areas with an above-average stability were $70.44 \%, 65.24 \%$, and $50.31 \%$ under three water levels, respectively. Furthermore, the decreasing tendency of the habitat stability expanded spatially. Areas with a higher stability on the west and east sides of the Poyang Lake also gradually became narrower, which indicated a decrease of the relative suitability of habitats.

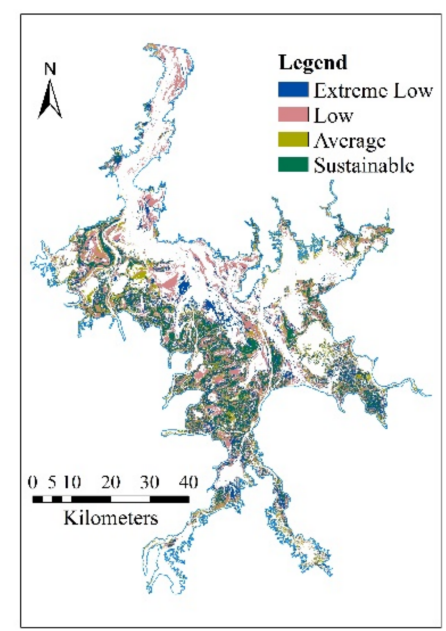

(a)

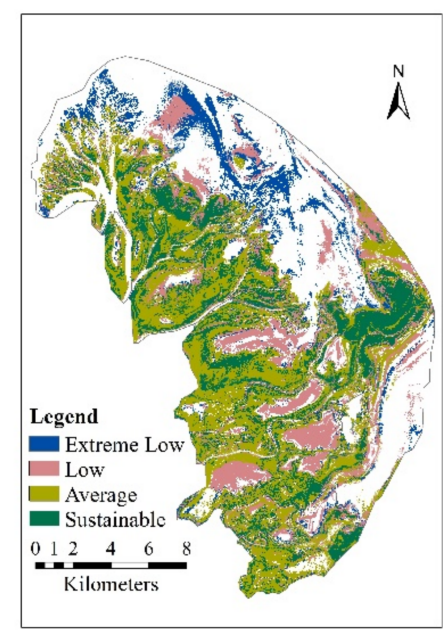

(b)

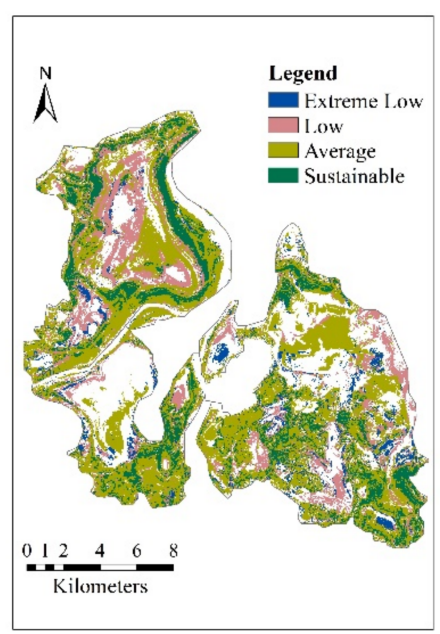

(c)

Figure 6. Sustainability of crane habitats in: (a) Poyang Lake wetland; (b) Nanjishan nature reserve; (c) Wucheng nature reserve.

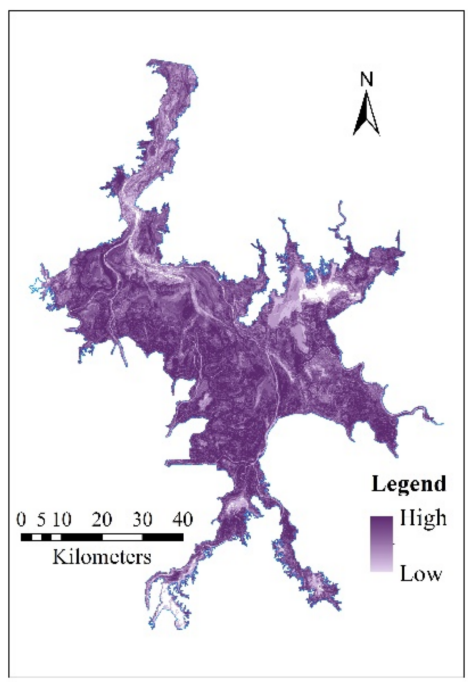

(a)

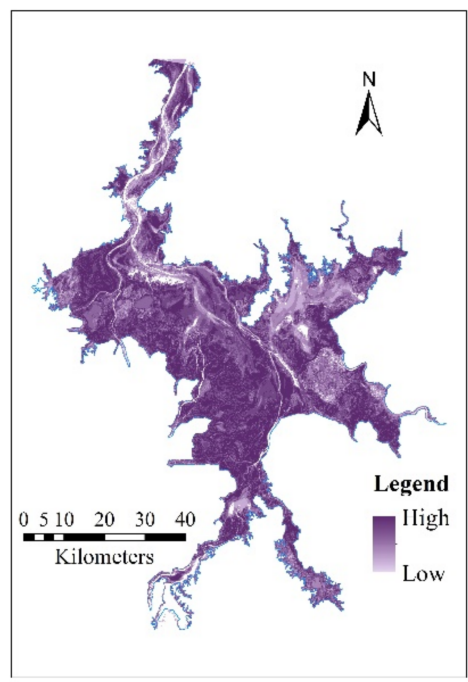

(b)

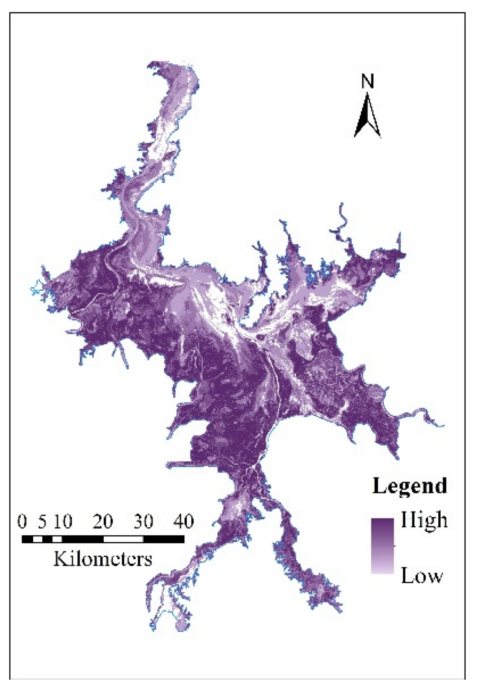

(c)

Figure 7. Stabilities of crane habitats in the Poyang Lake wetland under different hydrological conditions: (a) EL, extremely low level; (b) LL, low level; (c) AL, average level. Higher values indicate stronger stability of the crane habitats. 


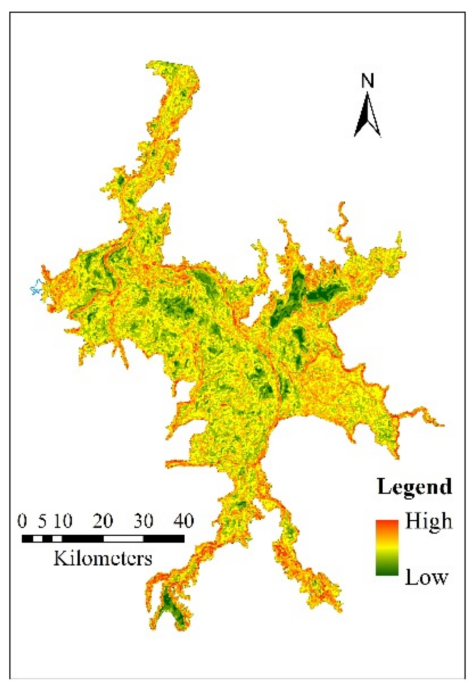

(a)

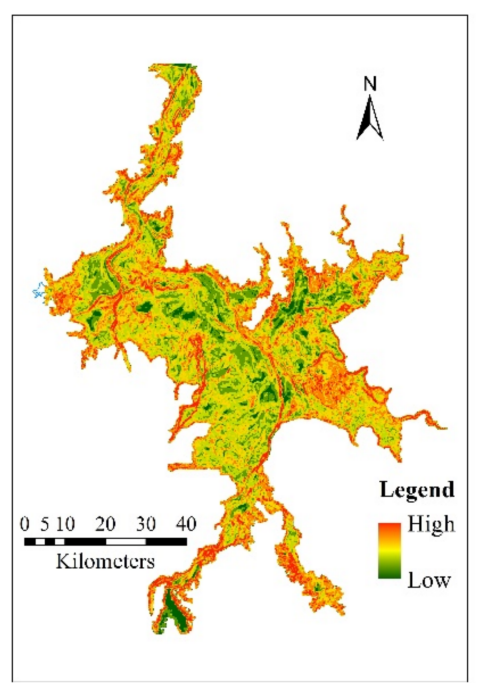

(b)

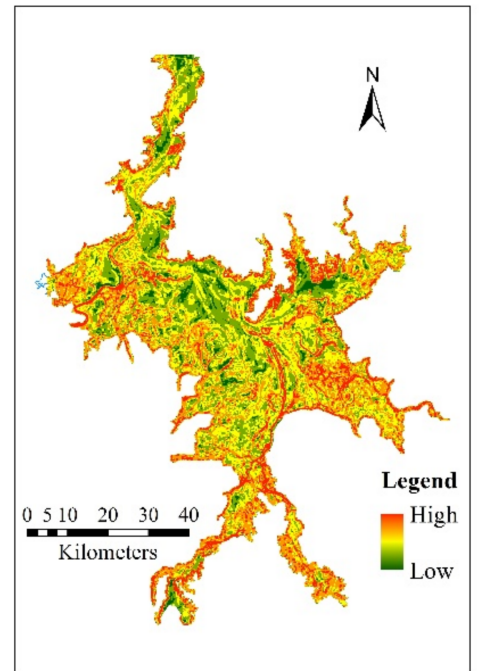

(c)

Figure 8. Varieties of crane habitats in the Poyang Lake wetland under different hydrological conditions: (a) EL, extremely low level; (b) LL, low level; (c) AL, average level. Higher values indicate stronger variety of the crane habitats.

Table 6. Area statistics of stabilities and varieties of crane habitats in the Poyang Lake wetland under different hydrological conditions $\left(\mathrm{km}^{2}\right)$.

\begin{tabular}{ccccc}
\hline $\begin{array}{c}\text { Hydrological } \\
\text { Conditions }\end{array}$ & Stability & Area & Variety & Area \\
\hline & Null & 71.99 & 1 & 83.93 \\
Extremely low water level & 1 & 165.57 & 2 & 302.48 \\
& 2 & 300.29 & 3 & 791.78 \\
& 3 & 482.69 & 4 & 1149.38 \\
& 5 & 792.21 & 5 & 893.16 \\
& 6 & 958.83 & 6 & 442.34 \\
Low water level & Null & 681.22 & 7 & 86.50 \\
& 1 & 166.66 & 1 & 144.31 \\
& 2 & 269.01 & 2 & 540.59 \\
& 3 & 427.18 & 3 & 943.39 \\
& 4 & 681.87 & 4 & 925.66 \\
& 5 & 947.71 & 5 & 812.85 \\
& Null & 970.53 & 6 & 394.49 \\
\hline & 1 & 322.21 & 1 & 181.88 \\
& 2 & 680.27 & 2 & 867.86 \\
& 3 & 714.49 & 3 & 1158.78 \\
& 4 & 813.06 & 4 & 991.69 \\
& & 925.37 & 5 & 552.43 \\
\hline
\end{tabular}

The cells with an above-average variety contributed $53.25 \%, 56.71 \%$, and $56.59 \%$ of the overall wetland area under extremely low, low, and average water levels, respectively (Table 6). However, the variety of the crane habitats in the main lake area and around the main channel of Poyang Lake gradually decreased as water level increased (Figure 8), and the decreasing tendency also expanded spatially. Moreover, the proportions of the areas with the lowest variety value also increased as water level increased, and they contributed $2.24 \%, 3.84 \%$, and $4.85 \%$ of the wetland area under three water levels, respectively (Table 6). The aggregation structure of the non-habitat areas of the Siberian cranes was partly strengthened, whereas the variety of the "Lake Enclosed in Autumn" regions was clearly enhanced. Thus, under extremely low to average water levels, the stability and 
variety of the crane habitats simultaneously decreased as water level increased, and the aggregation structure of the crane habitats was weakened, which is likely related to the habitat landscape and food resource changes induced by changing water levels [16,21,59].

\section{Discussion}

The selection of the crane habitats was previously found to be influenced by several factors, such as wetland area, water level, food distribution, vegetation height, and distance from human interference sources [71-73], among which the water level had the largest impact [74-77]. This study focused on the spatiotemporal variation of the Siberian crane habitats and the response to changing water levels in the Poyang Lake wetland. The findings are of great importance for wetland ecological environment governance, biodiversity protection, and supporting the conservation of the wintering grounds of the endangered Siberian crane.

The area, composition, and spatial aggregation effect of the crane habitats in the Poyang Lake wetland showed different tendencies over time and under different hydrological conditions. The majority of the aggregated habitats for the wintering Siberian cranes were found to be located in the "sheet" belts centered on the "Lake Enclosed in Autumn" regions. These areas exhibited strong stability under various water levels. This finding is consistent with several previous studies [44,58]. At present, there are some negative evaluations of how the "Lake Enclosed in Autumn" operation may affect the protection of wintering migratory birds in the Poyang Lake area. However, our study found that the distribution of hot spots of suitable habitats for the Siberian cranes were mainly found in the "Lake Enclosed in Autumn" regions. Although these are the result of artificial operations, there were still locations of potential habitats. Their existence has created a suitable habitat that is conducive to the foraging of wading birds and has also increased the growth period of aquatic animals such as fish $[13,59,78]$. The "Lake Enclosed in Autumn" operation has increased the shallow water area in the Poyang Lake wetland during dry years, which can enlarge wetland areas suitable for migratory birds.

The spatiotemporal characteristics of the Siberian crane habitats in the Poyang Lake wetland could be influenced by human activities such as sand dredging. Based on the sand dredging area and cumulative depth data of Poyang Lake in 2010, which were collected by Jiangxi Provincial Bureau of Surveying and Mapping Geographical Information, the stabilities of the crane habitats in the active areas of sand dredging were found to be generally lower than other areas under various water levels. Sand dredging activities can be preliminarily considered to be the potential determinant of the vulnerability of the Siberian crane habitats. Pearson correlation results also indicate that there was a statistically significant negative correlation between the sand dredging depth and the stability of the crane habitats. The negative correlations at extremely low and low water levels were obviously higher than that at average water level. The impact of sand dredging activities on the stability of the crane habitats has also various response to water level, and the negative influence was heavier at low water level than that at normal level.

Our study has demonstrated novel remote sensing and image processing methods to reveal new and important information about the complex Poyang Lake wetland system. However, there are still ways that these methods could be improved in future work. Due to the issues such as excessive cloud cover, limited image availability and huge workload of image processing, the remote sensing images used in our study were not taken at regular intervals, and therefore, a robust time series analysis of the variation of the crane habitats in the Poyang Lake wetland and its response to the hydrological processes was not possible here, but could be possible by employing more images in future efforts. In addition, the suitable habitats for wintering Siberian cranes in the Poyang Lake wetland were identified by including several specific landscape types. The crane habitat landscape has slight uncertainties due to factors such as food sources and thus there is considerable uncertainty in the clear identification of crane habitats; this could hopefully be improved by more detailed analyses. Moreover, this study is based on the statistical analysis of 
retrospective data and has not constructed any regressive or prospective models (e.g., the regressive analysis between habitat stability and sand dredging depth). The quantitative prediction of the spatiotemporal evolution of the crane habitats in the Poyang Lake wetland should be explored further using prediction modelling that can use our results as a base. Finally, a quantitative distribution of wintering Siberian cranes and their corresponding association to crane habitat distribution are another possible future research direction.

\section{Conclusions}

This study explored the spatiotemporal variation of suitable habitats of the wintering Siberian cranes in the Poyang Lake wetland and their response to changing water levels. The crane habitats indicated clear responses to different water levels and during different seasons. The habitat variability exhibited a gradual decreasing of the fragmentation degree over time, an obvious uncertainty of shape complexity, and a relatively stable connectivity. A consistent spatial pattern of highly aggregated distributions of the habitats was found to be associated with different water level conditions. The hot spots of the habitats formed multiple "sheet" belts centered on the "Lake Enclosed in Autumn" regions and the majority was distributed in sub-lakes of the southeast part of Poyang Lake and in the Nanjishan and Wucheng nature reserves. The cold spots indicated a spatial pattern of axial distributions which were mainly distributed in the main channels of the basins of Poyang Lake. The sustainable crane habitats were mainly distributed in the "Lake Enclosed in Autumn" regions and densely aggregated in the nature reserves. Under extremely low to average water level conditions, the stability and variety of the habitats simultaneously decreased as the water level increased, and the aggregation structure of the habitats weakened.

Author Contributions: Conceptualization, B.H. and S.Q.; methodology, L.Z. and B.H.; validation, B.H. and S.Q.; formal analysis, L.Z., Q.Z. and B.H.; investigation, L.Z., Q.Z. and P.N.; resources, S.Q. and B.H.; data curation, B.H. and S.Q.; writing—original draft preparation, L.Z.; writing-review and editing, B.H.; visualization, L.Z., P.N. and B.H.; supervision, B.H. and S.Q.; funding acquisition, B.H. and S.Q. All authors have read and agreed to the published version of the manuscript.

Funding: This research was funded by National Natural Science Foundation of China (grant numbers 42061075 and 41867012) and Opening Fund of Key Laboratory of Poyang Lake Wetland and Watershed Research (Jiangxi Normal University), Ministry of Education (grant number PK2019001).

Data Availability Statement: The data presented in this study are available on request from the corresponding author. The data are not publicly available due to the constraint in the consent.

Conflicts of Interest: The authors declare no conflict of interest.

\section{References}

1. Wang, Y. Poyang Lake and wintering Siberian cranes. Front. Ecol. Environ. 2020, 18, 100. [CrossRef]

2. Wang, W.; Fraser, J.D.; Chen, J. Wintering waterbirds in the middle and lower Yangtze River floodplain: Changes in abundance and distribution. Bird Conserv. Int. 2017, 27, 167-186. [CrossRef]

3. Huang, Z.; Lu, L.; Jiao, G.; Jiang, J.; Ye, Q. Analysis of the correlations between environmental factors and rare cranes in the Poyang Lake region of China. J. Great Lakes Res. 2018, 44, 140-148. [CrossRef]

4. Bai, Q.; Chen, J.; Chen, Z.; Dong, G.; Dong, J.; Dong, W.; Fu, V.W.K.; Han, Y.; Lu, G.; Li, J.; et al. Identification of coastal wetlands of international importance for waterbirds: A review of China Coastal Waterbird Surveys 2005-2013. Avian Res. $2015,6,12$. [CrossRef]

5. Gao, J.H.; Jia, J.; Kettner, A.J.; Xing, F.; Wang, Y.P.; Xu, X.N.; Yang, Y.; Zou, X.Q.; Gao, S.; Qi, S.; et al. Changes in water and sediment exchange between the Changjiang River and Poyang Lake under natural and anthropogenic conditions, China. Sci. Total Environ. 2014, 481, 542-553. [CrossRef] [PubMed]

6. Huang, F.; Yan, B.; Zhang, X.; Zhao, D.; Guo, L.; Wang, Y.; Xia, Z. Water Regime Evolution of Large Seasonal Lakes: Indicators for Characterization and an Application in Poyang Lake, China. Int. J. Environ. Res. Public Health 2018, 15, 2598. [CrossRef]

7. Zhang, Q.; Ye, X.; Werner, A.D.; Li, Y.; Yao, J.; Li, X.; Xu, C. An investigation of enhanced recessions in Poyang Lake: Comparison of Yangtze River and local catchment impacts. J. Hydrol. 2014, 517, 425-434. [CrossRef]

8. Heim, W.; Trense, D.; Sokolova, G.V.; Kitagawa, T. Increased Populations of Endangered Cranes After Amur River Flood. Waterbirds 2017, 40, 282-288. [CrossRef] 
9. Wang, Y.; Jia, Y.; Guan, L.; Lu, C.; Lei, G.; Wen, L.; Liu, G. Optimising hydrological conditions to sustain wintering waterbird populations in Poyang Lake National Natural Reserve: Implications for dam operations. Freshw. Biol. 2013, 58, 2366-2379. [CrossRef]

10. Wu, G.; Liu, Y. Assessment of the Hydro-Ecological Impacts of the Three Gorges Dam on China's Largest Freshwater Lake. Remote Sens. 2017, 9, 1069. [CrossRef]

11. Nie, X.; Hu, X.; Liu, G.; Jin, B.; Qin, H. Effects of water level on zooplankton community during "plate-shaped Lake Enclosed in Autumn" in a sub-lake of the Poyang lake. Acta Hydrobiol. Sin. 2019, 43, 402-414.

12. Shen, R.; Lan, Z.; Fang, C.; Chen, J. The dikes of the sub-lakes change soil carbon cycle in the littoral wetland in Poyang Lake. J. Lake Sci. 2018, 30, 1260-1270.

13. Guo, H.; Hu, B.; Li, Q. Effects of autumn fishery by Enclosing Plate-Shaped Lake on the winter migratory birds and conservation strategies in Nanji Wetland National Natural Reserve of the Poyang Lake, Jiangxi. Resour. Environ. Yangtza Basin 2014, $23,46-52$. (In Chinese)

14. Dronova, I.; Beissinger, S.R.; Burnham, J.W.; Gong, P. Landscape-Level Associations of Wintering Waterbird Diversity and Abundance from Remotely Sensed Wetland Characteristics of Poyang Lake. Remote Sens. 2016, 8, 462. [CrossRef]

15. Zhang, Q.; Qi, S.; Hu, M. The positive evaluation of "Lake Enclosed in Autumn" on the habitat of winter bird in Poyang lake Wetlands. Jiangxi Sci. 2018, 36, 250-255. (In Chinese)

16. Jiang, F.; Qi, S.; Liao, F.; Ding, M.; Wang, Y. Vulnerability of Siberian crane habitat to water level in Poyang Lake wetland, China. Gisci. Remote Sens. 2014, 51, 662-676. [CrossRef]

17. You, H.; Xu, L.; Jiang, J.; Wang, X.; Huang, Q.; Liu, G. The effects of water level fluctuations on the wetland landscape and waterfowl habitat of Poyang lake. Fresen. Environ. Bull. 2014, 7A, 1650-1661.

18. Yang, Y.; Zhan, A.; Cao, L.; Meng, F.; Xu, W. Selection of a marker gene to construct a reference library for wetland plants, and the application of metabarcoding to analyze the diet of wintering herbivorous waterbirds. PeerJ 2016, 4, e2345. [CrossRef]

19. Chiba, A. Wintering Behavior of a Siberian Crane Grus leucogeranus in Niigata, Japan, with Special Regard to Food, Foraging and Vocal Habits. Ornithol. Sci. 2018, 17, 187-194. [CrossRef]

20. Morris, K.M.; Soehren, E.C.; Woodrey, M.S.; Rush, S.A. Habitat-Suitability Model for the Yellow Rail (Coturnicops noveboracensis) in the Northern Gulf Coast of Alabama and Mississippi, USA. Remote Sens. 2020, 12, 848. [CrossRef]

21. Fan, Y.; Zhou, L.; Cheng, L.; Song, Y.; Xu, W. Foraging behavior of the Greater White-fronted Goose (Anser albifrons) wintering at Shengjin Lake: Diet shifts and habitat use. Avian Res. 2020, 11, 3. [CrossRef]

22. Jia, Y.; Jiao, S.; Zhang, Y.; Zhou, Y.; Lei, G.; Liu, G. Diet Shift and Its Impact on Foraging Behavior of Siberian Crane (Grus Leucogeranus) in Poyang Lake. PLoS ONE 2013, 8, e65843. [CrossRef] [PubMed]

23. Sun, Z.; Huang, Y. Analysis on the Characteristics of Feeding Habitat of the Wintering Siberian Crane in Poyang Lake. Chin. J. Zool. 2010, 45, 46-52.

24. Recher, H.F.; Davis, W.E., Jr. Foraging behaviour of mulga birds in Western Australia. I. Use of resources and temporal effects. Pac. Conserv. Biol. 2018, 24, 74. [CrossRef]

25. Zhou, B.; Zhou, L.; Chen, J.; Cheng, Y.; Xu, W. Diurnal Time-Activity Budgets of Wintering Hooded Cranes (Grus monacha) in Shengjin Lake, China. Waterbirds 2010, 33, 110-115. [CrossRef]

26. Chen, B.; Cui, P.; Xu, H.; Lu, X.; Lei, J.; Wu, Y.; Shao, M.; Ding, H.; Wu, J.; Cao, M.; et al. Assessing the Suitability of Habitat for Wintering Siberian Cranes (Leucogeranus leucogeranus) at Different Water Levels in Poyang Lake Area, China. Pol. J. Ecol. 2016, 64, 84-97. [CrossRef]

27. Bancroft, G.T.; Gawlik, D.E.; Rutchey, K. Distribution of Wading Birds Relative to Vegetation and Water Depths in the Northern Everglades of Florida, USA. Waterbirds 2002, 25, 265-277.

28. Xia, S.; Xia, S.; Wang, Y.; Wang, Y.; Lei, G.; Lei, G.; Liu, Y.; Liu, Y.; Lei, J.; Lei, J.; et al. Restriction of Herbivorous Waterbird Distributions in the Middle and Lower Yangtze River Floodplain in View of Hydrological Isolation. Wetlands 2017, 37, 79-88. [CrossRef]

29. Coxen, C.L.; Frey, J.K.; Carleton, S.A.; Collins, D.P. Species distribution models for a migratory bird based on citizen science and satellite tracking data. Glob. Ecol. Conserv. 2017, 11, 298-311. [CrossRef]

30. Bysykatova, I.; Germogenov, N.; Solomonov, N.; Sleptcov, S.; Vladimirtseva, M.; Egorov, N. C-2028: Rare and endangered bird of Northeast Eurasia, the Siberian white crane grus leucogeranus: Habitats, ecology, migration, wintering. Cryobiology 2014, 69, 522-523. [CrossRef]

31. Musilová, Z.; Musil, P.; Zouhar, J.; Romportl, D. Long-term trends, total numbers and species richness of increasing waterbird populations at sites on the edge of their winter range: Cold-weather refuge sites are more important than protected sites. J. Ornithol. 2015, 156, 923-932. [CrossRef]

32. Deng, F.; Wang, X.; Cai, X.; Li, E.; Jiang, L.; Li, H.; Yan, R. Analysis of the relationship between inundation frequency and wetland vegetation in Dongting Lake using remote sensing data. Ecohydrology 2014, 7, 717-726. [CrossRef]

33. Zhang, L.; Yin, J.; Jiang, Y.; Wang, H. Relationship between the hydrological conditions and the distribution of vegetation communities within the Poyang Lake National Nature Reserve, China. Ecol. Inform. 2012, 11, 65-75. [CrossRef]

34. Wang, S.; Zhang, L.; Zhang, H.; Han, X.; Zhang, L. Spatial-Temporal Wetland Landcover Changes of Poyang Lake Derived from Landsat and HJ-1A/B Data in the Dry Season from 1973-2019. Remote Sens. 2020, 12, 1595. [CrossRef] 
35. Zheng, M.; Zhou, L.; Zhao, N.; Xu, W. Effects of variation in food resources on foraging habitat use by wintering Hooded Cranes (Grus monacha). Avian Res. 2015, 6, 11. [CrossRef]

36. Mao, Q.; Liao, C.; Wu, Z.; Guan, W.; Yang, W.; Tang, Y.; Wu, G. Effects of Land Cover Pattern Along Urban-Rural Gradient on Bird Diversity in Wetlands. Diversity 2019, 11, 86. [CrossRef]

37. Bonthoux, S.; Lefèvre, S.; Herrault, P.-A.; Sheeren, D. Spatial and Temporal Dependency of NDVI Satellite Imagery in Predicting Bird Diversity over France. Remote Sens. 2018, 10, 1136. [CrossRef]

38. An, A.; Zhang, Y.; Cao, L.; Jia, Q.; Wang, X. A potential distribution map of wintering Swan Goose (Anser cygnoides) in the middle and lower Yangtze River floodplain, China. Avian Res. 2018, 9, 43. [CrossRef]

39. Tang, X.; Li, H.; Xu, X.; Yang, G.; Liu, G.; Li, X.; Chen, D. Changing land use and its impact on the habitat suitability for wintering Anseriformes in China's Poyang Lake region. Sci. Total Environ. 2016, 557-558, 296-306. [CrossRef]

40. Liang, K.; Yan, G. Application of Landsat Imagery to Investigate Lake Area Variations and Relict Gull Habitat in Hongjian Lake, Ordos Plateau, China. Remote Sens. 2017, 9, 1019. [CrossRef]

41. Jiang, H.; He, C.; Sheng, L.; Tang, Z.; Wen, Y.; Yan, T.; Zou, C. Hydrological Modelling for Siberian Crane Grus Leucogeranus Stopover Sites in Northeast China. PLoS ONE 2015, 10, e122687. [CrossRef] [PubMed]

42. Liu, X.; Lu, Q.; Zhou, Y.; Li, K.; Xu, Y.; Lv, Q.; Qin, J.; Ouyang, S.; Wu, X. Community characteristics of phytoplankton and management implications in Poyang Lake Basin. Limnology 2020, 21, 207-218. [CrossRef]

43. Royan, A.; Hannah, D.M.; Reynolds, S.J.; Noble, D.G.; Sadler, J.P. River birds' response to hydrological extremes: New vulnerability index and conservation implications. Biol. Conserv. 2014, 177, 64-73. [CrossRef]

44. Zhao, H.; Wang, Y.; Xu, B.; Chen, X.; Jiang, Z. Exploring an efficient habitat index for predicting population and abundance of migratory birds in Poyang Lake Wetland, South China. Acta Ecol. Sin. 2018, 38, 381-390. [CrossRef]

45. Jia, Y.; Guan, L.; Wang, Y.; Liu, G.; Lei, G.; Wen, L. Combining Population Growth Model and Generalized Additive Model to Determine Optimal Water Level FOR Waterbird Conservation: A Case Study of Siberian Crane (Leucogeranus Leucogeranus) in Lake Poyang, China. River Res. Appl. 2016, 32, 100-109. [CrossRef]

46. Wu, X.; Lv, M.; Jin, Z.; Michishita, R.; Chen, J.; Tian, H.; Tu, X.; Zhao, H.; Niu, Z.; Chen, X.; et al. Normalized difference vegetation index dynamic and spatiotemporal distribution of migratory birds in the Poyang Lake wetland, China. Ecol. Indic. 2014, 47, 219-230. [CrossRef]

47. Kuan, R.; Zhou, Y.; Li, X.; Tian, B. Spatial fuzzy comprehensive assessmentof bird habitat suitability in Chongming Dongtan. Resour. Environ. Yangtze Basin 2009, 18, 229-233.

48. Rolland, V.; Barbraud, C.; Weimerskirch, H. Combined effects of fisheries and climate on a migratory long-lived marine predator. J. Appl. Ecol. 2008, 45, 4-13. [CrossRef]

49. Ramírez, F.; Gutiérrez-Expósito, C.; Afán, I.; Giménez, J.; de Stephanis, R.; Forero, M.G. Human influence on gull non-breeding distribution: Potential consequences of changes in fishing practices. Mar. Ecol. Prog. Ser. 2015, 527, 221-232. [CrossRef]

50. Giacomazzo, M.; Bertolo, A.; Brodeur, P.; Massicotte, P.; Goyette, J.; Magnan, P. Linking fisheries to land use: How anthropogenic inputs from the watershed shape fish habitat quality. Sci. Total Environ. 2020, 717, 135377. [CrossRef]

51. Cheng, J.; Xu, L.; Feng, W.; Fan, H.; Jiang, J. Changes in Water Level Regimes in China's Two Largest Freshwater Lakes: Characterization and Implication. Water-Sui 2019, 11, 917. [CrossRef]

52. Han, X.; Feng, L.; Hu, C.; Chen, X. Wetland changes of China's largest freshwater lake and their linkage with the Three Gorges Dam. Remote Sens. Environ. 2018, 204, 799-811. [CrossRef]

53. Zhang, J.; Huang, T.; Chen, L.; Zhu, D.Z.; Zhu, L.; Feng, L.; Liu, X. Impact of the Three Gorges Reservoir on the hydrologic regime of the river-lake system in the middle Yangtze River. J. Clean. Prod. 2020, 258, 121004. [CrossRef]

54. Ren, J.; Zheng, Z.; Li, Y.; Lv, G.; Wang, Q.; Lyu, H.; Huang, C.; Liu, G.; Du, C.; Mu, M.; et al. Remote observation of water clarity patterns in Three Gorges Reservoir and Dongting Lake of China and their probable linkage to the Three Gorges Dam based on Landsat 8 imagery. Sci. Total Environ. 2018, 625, 1554-1566. [CrossRef]

55. Liu, Y.; Fan, N.; Yu, X.; Xia, S.; Qi, S. Identification of Wetland Boundaries of Poyang Lake and Analysis of Seasonal Change Based on Remote Sensing and GIS technology. Resour. Sci. 2010, 32, 2239-2245. (In Chinese)

56. Hui, F.; Xu, B.; Huang, H.; Yu, Q.; Gong, P. Modelling spatial-temporal change of Poyang Lake using multitemporal Landsat imagery. Int. J. Remote Sens. 2008, 29, 5767-5784. [CrossRef]

57. Zhang, N.; Li, Y.; Shan, J.; Tu, X.; Zhang, Y.; Wang, L.; Ying, Q. Community structure, abundance and spatial distribution of water birds wintering in Poyang Lake wetland. J. Lake Sci. 2019, 31, 183-194.

58. Xia, S.; Yu, X.; Fan, N. The wintering habitats of migrant birds and their relationship with water level in poyang lake, China. Resour. Sci. 2010, 32, 2072-2078. (In Chinese)

59. Qi, S.; Zhang, Q.; Jiang, F.; Liao, F. Study on the effects on the landscape spatial pattern of the wintering birds' habitat from lake level in Poyang Lake Wetland. J. Nat. Resour. 2014, 29, 1345-1355. (In Chinese)

60. Degtyarev, V.G.; Sleptsov, S.M.; Pshennikov, A.E. Territoriality in the eastern population of the Siberian Crane, Grus leucogeranus. Russ. J. Ecol. 2013, 44, 207-212. [CrossRef]

61. Zhi, Y.; Lu, P.; Dai, N.; Shao, M.; Zeng, J. Foraging behaviour of Siberian Cranes in lotus pond habitats surrounding Poyang Lake. Acta Ecol. Sin. 2019, 39, 4266-4272. 
62. Cui, Y.; Dong, B.; Chen, L.; Gao, X.; Cui, Y. Study on habitat suitability of overwintering cranes based on landscape pattern change-A case study of typical lake wetlands in the middle and lower reaches of the Yangtze River. Environ. Sci. Pollut. Res. 2019, 26, 14962-14975. [CrossRef]

63. Cong, P.; Chen, K.; Qu, L.; Han, J. Dynamic Changes in the Wetland Landscape Pattern of the Yellow River Delta from 1976 to 2016 Based on Satellite Data. Chin. Geogr. Sci. 2019, 29, 372-381. [CrossRef]

64. Liu, X.; Zhang, Y.; Dong, G.; Hou, G.; Jiang, M. Landscape Pattern Changes in the Xingkai Lake Area, Northeast China. Int. J. Environ. Res. Public Health 2019, 16, 3820. [CrossRef] [PubMed]

65. Zhong, Y.; Lin, A.; He, L.; Zhou, Z.; Yuan, M. Spatiotemporal Dynamics and Driving Forces of Urban Land-Use Expansion: A Case Study of the Yangtze River Economic Belt, China. Remote Sens. 2020, 12, 287. [CrossRef]

66. Naha, D.; Sathyakumar, S.; Dash, S.; Chettri, A.; Rawat, G.S. Assessment and prediction of spatial patterns of human-elephant conflicts in changing land cover scenarios of a human-dominated landscape in North Bengal. PLoS ONE 2019, 14, e210580. [CrossRef] [PubMed]

67. Qi, J.; Liu, H.; Liu, X.; Zhang, Y. Spatiotemporal evolution analysis of time-series land use change using self-organizing map to examine the zoning and scale effects. Comput. Environ. Urban Syst. 2019, 76, 11-23. [CrossRef]

68. Xi, Y.; Thinh, N.; Li, C. Spatio-Temporal Variation Analysis of Landscape Pattern Response to Land Use Change from 1985 to 2015 in Xuzhou City, China. Sustainability 2018, 10, 4287. [CrossRef]

69. Cliff, A.D.; Ord, J.K. Spatial Processes: Models and Applications; Pion Limited: London, UK, 1981.

70. Getis, A.; Ord, J.K. The Analysis of Spatial Association by Use of Distance Statistics. Geogr. Anal. 1992, 24, 189-206. [CrossRef]

71. You, H.; Fan, H.; Xu, L.; Wu, Y.; Liu, L.; Yao, Z. Poyang Lake Wetland Ecosystem Health Assessment of Using the Wetland Landscape Classification Characteristics. Water 2019, 11, 825. [CrossRef]

72. Fernandez, C.; Spayd, J.; Brooks, R.P. Landscape Indicators and Ecological Condition for Mapped Wetlands in Pennsylvania, USA. Wetlands 2019, 39, 705-716. [CrossRef]

73. Amaral, Y.T.; Santos, E.M.D.; Ribeiro, M.C.; Barreto, L. Landscape structural analysis of the Lençóis Maranhenses national park: Implications for conservation. J. Nat. Conserv. 2019, 51, 125725. [CrossRef]

74. Senner, N.R.; Moore, J.N.; Seager, S.T.; Dougill, S.; Kreuz, K.; Senner, S.E. A salt lake under stress: Relationships among birds, water levels, and invertebrates at a Great Basin saline lake. Biol. Conserv. 2018, 220, 320-329. [CrossRef]

75. Gao, Y.; Xie, Y.; Zou, D. Hydrological regime change and its ecological responses in East Dongting Lake, China. Ecohydrol. Hydrobiol. 2020, 20, 142-150. [CrossRef]

76. Zhang, D.; Zhou, L.; Song, Y. Effect of water level fluctuations on temporal-spatial patterns of foraging activities by the wintering Hooded Crane (Grus monacha). Avian Res. 2015, 6, 51-59. [CrossRef]

77. Gnass Giese, E.E.; Howe, R.W.; Wolf, A.T.; Niemi, G.J. Breeding birds and anurans of dynamic coastal wetlands in Green Bay, Lake Michigan. J. Great Lakes Res. 2018, 44, 950-959. [CrossRef]

78. Wang, W.; Fraser, J.D.; Chen, J. Distribution and Long-Term Population Trends of Wintering Waterbirds in Poyang Lake, China. Wetlands 2019, 39, 125-135. [CrossRef] 